\title{
Teologi di Asia dari Perspektif Perjanjian Lama
}

\author{
V. Mangandar Siringoringo \\ Sekolah Tinggi Teologi Sumatera Utara \\ ringovm@yahoo.com
}

\begin{abstract}
When Theology in Asia being compared to theology in the West is very different. Asia referred to here is India, Japan and Korea. Basically, in these three nations theology was built from the life experiences of the people, albeit differently from each nation. Basically, these three nations have a society that lives in agony controlled by people in power. In India, it is controlled by a higher caste; in Japan dominated by Buddhism; in Korea by the ruling class. Based on the experiences experienced by the people of these three nations, the Church struggled to free them from the suffering they experienced.
\end{abstract}

Keywords: church; theology of Asia; Old Testament; people; suffering

\begin{abstract}
Abstrak: Theologi di Asia jika dibandingkan dengan theologi di Barat sangat berbeda. Asia dimaksud di sini adalah India, Jepang dan Korea. Secara pokok pada ketiga bangsa ini theologi dibangun dari pengalaman hidup masyarakat, walaupun secara berbeda-beda dari setiap bangsa. Pada dasarnya ketiga bangsa ini mempunyai masyarakat yang hidup dalam penderitaan yang dikuasai oleh orang-orang yang berkuasa. Di India, dikuasai oleh kasta yang lebih tinggi; di Jepang dikuasai oleh agama Buddhis; di Korea oleh kelas yang berkuasa. Berdasarkan pengalaman yang dialami oleh masyarakat dari ketiga bangsa ini, maka Gereja bergumul untuk membebaskan mereka dari penderitaan yang mereka alami.
\end{abstract}

Kata Kunci: Gereja; penderitaan; Perjanjian Lama; rakyat; teologi Asia

\section{PENDAHULUAN}

Membahas "Theologi di Asia dari Perspektif Perjanjian Lama" merupakan suatu tugas yang sulit. Namun sangat menarik untuk diteliti, mengingat, secara umum ada kesamaan dengan kehidupan umat Israel ketika mereka berada di Mesir. Mengenai 'theologi di Asia" ini, Samuel Amirthan dan John S.Pobee menyebutnya "theologi oleh rakyat" dalam arti berbicara tentang pekerjaan theologis yang dilakukan oleh blok sosial orang-orang yang tertindas yang hidup di tengah-tengah bangsa-bangsa di dunia dewasa ini, dan secara khusus yang dieksploitir di Dunia ketiga (Asia). Di sini orang-orang miskin merupakan suatu realitas yang sedang menderita dan berteriak ke langit seperti pada zaman Musa. ${ }^{1}$

\footnotetext{
${ }^{1}$ Samuel Amirthan dan John S. Pobee, Teologi oleh Rakyat (Jakarta: BPK Gunung Mulia, 1993), 2 Bahkan dalam pengertian orang-orang miskin dan tertindas, kata 'rakyat' telah diinterpretasikan oleh beberapa orag sebagai suatu kelas sosialseperti para buruh industri atau pertanian, dsb. Maka rakyat di sini, bukan sekedar kelas-kelas tertindas, tetapi bloksosial orang-orang tertindas pada suatu bangsa.
} 


\section{Teologi di India}

\section{India dalam Sejarah}

India adalah merupakan suatu bangsa yang miskin. Kemiskinan dan sumber kemiskinan ada di mana-mana. Kehidupan telah dihancurkan dan dirusakkan serta dijadikan sesuatu yang jahat. Kejahatan terus mengalir dari kerusakan dan kekurangan yang terus menerus. Semuanya itu tidak menyenangkan untuk dilihat, tetapi itulah suatu kenyataan di India. India penuh dengan penderitaan, dan itu terjadi di mana-mana terutama dalam hal kelaparan, penyakit epidemi. Sudah tentu, bukan kelaparan satu-satunya realitas yang mempengaruhi India, tetapi masalah inilah yang ditempatkan dalam konteks pembicaraan di sini. ${ }^{2}$

Masalah kelaparan ini adalah mengungkapkan suatu gambaran India berada di bawah lapis- an tipis kemakmuran dari segelintir orang di puncaknya. Ini juga menggambarkan keadaan sosial yang sangat kontras di India. Sebagian sangat kaya dan banyak sekali yang miskin. Kontras seperti ini sangat nyata di kota-kota, seperti Calkuta di mana kelaparan terjadi yang begitu mengerikan. Situasi ini semakin diperumit oleh kemasabodohan rakyat sendiri. Gambaran ini menunjukkan kemiskinan di mana-mana. ${ }^{3}$

Unsur-unsur ini masih terus berlangsung sampai masa kini, walaupun India telah mencapai kemajuan. India termasuk dalam kelompok negara yang menggunakan energi nuklir, dengan maksud agar dapat membebaskan diri masalah abadi kemiskinan. Tapi nyatanya, India belum terbebaskan dari kemiskinan massalnya. Setengah dari populasi India masih hidup dalam garis kemiskinan yang menimbulkan putus asa. Karenanya, kemiskinan di India merupakan kemiskinan massal, dan dengan demikian kemiskinan massal ini belum pernah terjadi dalam sejarah dan tidak ada bandingannya di tempat mana pun di dunia ini. Karena itu tidak heran, India digambarkan samudera kemiskinan. ${ }^{4}$

\section{Orang India Suatu Bangsa Religius}

Dalam konteks pembahasan theologia di India, perlu dibicarakan mengenai kehidupan bangsa India. Tak dapat dibantah, bahwa orang-orang India adalah bangsa yang religius. Di sana kita temui Hinduisme, Jainisme dan Skhisme lahir di sana, namun pun demikian India adalah negara sekuler. Pernyataan ini bermaksud untuk menghindari penentuan suatu agama menjadi agama resmi bangsa India. Setiap agama dianggap sama di hadapan hukum. Berdasarkan statistik yang tercatat yaitu Hinduisme 78,8\%; Buddhisme 0,8\%; Sikhisme 2\%; Islam 11,6\%; agama tradisionalisme 40 juta; Kristen 3.9\%; dan tidak beragama hanya $0,8 \%$. Dari statistik ini jelas kita lihat bahwa India adalah bangsa yang sangat religius. 5

\section{Gereja dan Masalah Sistem Kasta}

Dalam kaitan ini, perlu dibicarakan bagaimana Gereja-gereja memperhatikan masalah sosial di India. Kasta dalam struktur sosial menghasilkan ketidakadilan, karena itu Gereja-

\footnotetext{
${ }^{2}$ A.A.Yewangoe, Theologia Crusis di Asia (Jakarta: BPK Gunung Mulia, 1989), 37

${ }^{3}$ Ibid.

${ }^{4}$ Ibid, 39

${ }^{5}$ Bd. Douglas J.Elwood, Teologi Kristen Asia (Jakarta: BPK Gunung Mulia, 1992), 257
} 
gereja bersikap menentangnya. Ini nampak dari pertumbuhan-pertumbuhan Gereja-gereja di India. Di mana keba- nyakan dari orang Kristen baru berasal dari kasta tertindas, secara khusus di kalangan Gereja Mar Thoma. Menjadi orang Kristen sepenuhnya terhisap dalam persekutuan, apa pun latar belakang sosialnya. Terutama di daerah Telagu, yang menjadi Kristen terutama berasal dari kalangan kasta rendah. Melalui peristiwa-peristiwa seperti ini, Gereja-gereja telah membuktikan arti persaudaraan di dalam Kristus, karena sistem kasta tidak konsisten dengan persaudaraan. Dari sini jelas bahwa Gereja-gereja menyampaikan pesan 'pembebasan' dari sistem kasta, juga sumbangan bagi pembangunan kehidupan nsional. Namun perjuangan ini belum mencapai puncaknya. ${ }^{6}$

Ini nyata dari adanya Gereja-gereja yang mempertahankan kasta dalam perkawinan, pemilihan majelis Kristen, pemilihan uskup, penunjukan pada posisi diberbagai lembaga Kristen: sekolah, sekolah tinggi, rumah sakit, dll. Ini terjadi di kalangan orang-orang Kristen India Utara, dan juga dalam sikap missionaris, khususnya berasal dari Missionaris London, tampak cendrung kepada kaum Brahma yang bertobat. Karena itu, di kalangan Gereja-gereja India dilakukan promosi transformasi batin dengan membuat orang sadar akan harkatnya dan mencoba mencapai hubungan yang lebih sehat antar kelompok-kelompok. Untuk mengatasi masalah ini, digalakkan perkawinan antar kasta melalui pendidikan bersama di sekolah-sekolah dan sekolah tinggi.Ternyata, masalah kasta masih merupakan hal yang sulit dipecahkan. ${ }^{7}$

\section{Gereja dan Kemiskinan Massal}

Masalah kemiskinan juga hal yang penting untuk diperhatikan. Gereja-gereja menaruh banyak perhatian terhadap masalah ini. Ibu Theresia misalnya, berupaya menolong kaum miskin, hidup bersama dengan orang yang kehilangan dengan segalanya, menghibur orang yang hampir mati, semua ini adalah ungkapan arti amal Kristen. Amal seperti ini amat berarti.Tapi India masih menghadapi masalah struktur masyarakat yang tidak adil. Dan kemiskinan massal hanyalah suatu gejala penyakit yang lebih dalam. Gereja berusaha menghadapi masalah ini, untuk ini Gereja harus memperhatikan para korban masyarakat yang tak adil. Gereja-gereja masa kini berupaya lebih banyak memberi perhatian. ${ }^{8}$

Ada suatu kelompok kecil bernama Liga Industri Kota Bombay untuk Pembangunan (BUILD) memberikan contoh secara konkrit tentang apa artinya keadilan sosial sesungguhnya dalam kehidupan praktis. Meskipun kecil, kegiatan kelompok ini dipandang sebagai tanda yang hidup dari Gereja yang menghadapi masalah kemiskinan massal.Sudah tentu muncul kritik-kritik dari BUILD terhadap Gereja-gereja, supaya Gereja-gereja hanya sebagai objek perbuatan amal, tetapi agar melibatkan diri dalam gerekan menuju suatu tatanan baru. Walaupun begitu, gerakan ini masih tepat disebut Gereja, diilhami oleh pemahaman baru mengenai makna Injil, kabar baik untuk kaum miskin. ${ }^{9}$

\footnotetext{
${ }^{6}$ Yewangoe, Theologia Crusis di Asia, 57-58

${ }^{7}$ Ibid., 59-60

${ }^{8}$ Ibid., 60

${ }^{9}$ Ibid., 61
} 
Karena itu, semua tindakan ini didorong oleh keyakinan bahwa Yesus Kristus mengindenti- fikasikan diri-Nya dengan kaum miskin dan terbuang. Ia memberitakan kabar baik kepada mereka. Bila Gereja-gereja ingin setia kepada Tuhan-Nya, menolong kuam miskin dan kaum terbuang untuk mendengarkan kabar baik ini. Gereja-gereja di India harus memihak pada kaum miskin. Kabar baik mengenai kelahiran Yesus disampaikan kepada sekelompok kaum tidak berkasta. Yesus bertumbuh sebagai seorang tukang kayu. Itu berarti, Yesus mengetahui dan mengalami nasib yang menyedih- kan di dalam tubuh-Nya sendiri. Dalam penderitaan kepada kaum miskin, penderitaan Yesus berlanjut. Kaum miskin harus memikul salib, segala sesuatu yang membuat hidup ini sulit sebagai kaum miskin setiap hari tergantung pada salib mereka, Yesus pun tergantung bersama mereka dalam solidaritas salib ini. ${ }^{10}$

\section{Kemiskinan dan Perjanjian Lama}

Masalah kemiskinan di India secara umum, oleh para theolog India lebih menghubungkannya dengan Yesus Kritus. Misalnya, Vengal Chakkararai terkenal dengan theologia salibnya, yaitu berusaha menemukan makna salib bagi kehidupan orang percaya tentang bagaimana salib membawa moksa (kelepasan sempurna). Sedangkan M.M.Thomas yaitu seorang humanisme baru yang berdasar pada tindakan penjelmaan Allah di dalam Yesus Kritus. Dan bagi S.J.Samartha bahwa salib adalah lambang penerimaan akan penderitaan untuk menggenapi maksud kasih dalam realitas sejarah manusia. ${ }^{11}$ Dari sini jelas bagi kita, secara umum kemiskinan dilihat dalam konteks kehidupan Yesus Kristus yang miskin sejak peristiwa kelahiran sampai kematian-Nya di salib.

Namun tidak berarti, bahwa Perjanjian Lama tidak berbicara sebagai dasar dalam rangka pembebasan dari kemiskinan dalam gereja-gereja India. Dalam hubungan ini Samuel Amirtham dan John S.Pobee menuliskan bahwa telah ada pengakuan tersiar luas bawa tema utama Perjanjian Lama ialah keluaran dari perbudakan di Mesir dan tema Perjanjian Baru adalah keluaran yang digenapi oleh Yesus di Yerusalem bagi semua orang. ${ }^{12}$ Selain dari tema peristiwa keluaran dalam Perjanjian Lama, nas-nas lain yang dipakai dalam konteks pembebasan dari penderitaan dan kemiskinan ini juga Hakim-hakim (Yes 30-31; 40:3-5; 41:17-20; 43:14-21; 44:27; 48:20-21; 49:8-13; 50:1-3; 51:9-11; 52:36; 52:11-12; 55:12-13; Yer 26-30). ${ }^{13}$

Namun hal yang tak boleh dilupakan adalah masalah kemiskinan di India adalah masalah bersama, sebagaimana kita lihat dalam kehidupan bangsa Israel dalam peristiwa keluaran dari Mesir, yang melukiskan kemiskinan bangsa Israel secara bersama (massal). Ini dikarenakan, hubungan penindasan sangat dengan kemiskinan. Dalam sejarahnya, orang yang ditindas akan mengalami kemiskinan, dan tidak akan pernah mengalami kekayaan. Bangsa Israel mengalami kemiskinan ketika mereka mengalami penindasan bangsa Mesir. Juga pengalaman hamba Tuhan yang menderita dalam kitab Yesaya

\footnotetext{
${ }^{10}$ Elwood, Teologi Kristen Asia, 111-112

${ }^{11}$ Yewangeo, Theologia Crusis di Asia, 63, 90, 106

${ }^{12}$ Amirtham dan Pobee, Teologi oleh Rakyat, 21

${ }^{13}$ Marthinus Th.Mawene, Teologi Kemerdekaan (Jakarta: BPK Gunung Mulia, 2004), 12-46, 100-123.
} 
menyatakan suatu kemiskinan yang dialaminya. Maka baik pengalaman Israel dalam keluaran dan pengalaman hamba Tuhan dalam kitab Yesaya juga melukiskan penderitaan dan kemiskinan orang India. ${ }^{14}$

Dalam Keluaran 19 dikatakan bahwa Allah adalah El-Shaddai telah menjadi ElImanu (Imanuel), Allah yang ada bersama kita. Kuasa-Nya diberikan kepada rakyat dan rakyat menjadi berkuasa. Bahasa Alkitab mengatakan "Aku adalah Allahmu dan kamu adalah umat-Ku." Ini berarti Allah hadir di tengah-tengah orang India yang mengalami pederitaan dan kemiskinan itu. Allah di sana mau memelihara mereka, karena Allah memperhatikan orang-orang miskin. Dalam Ulangan 15:11 dikatakan: "Haruslah engkau membuka tangan lebar-lebar bagi saudaramu yang tertindas dan yang miskin di negerimu." Dengan nas ini mau dinyatakan bahwa Allah hadir di tengah-tengan orang India yang miskin untuk menolong mereka, karena Allah menyamakan diri-Nya dengan orang-orang miskin. ${ }^{15}$

Maka jelas bagi kita di mana sumber-sumber Perjanjian Lama ditafsirkan guna menjelaskan bagaimana Allah berhubungan dengan kemiskinan yang berdasar kepada kitab Undang-undang (Kitab Perjanjian, Hukum-hukum Ulangan, dsb) yang mendukung hak-hak orang miskin, berdasar- kan pada latar belakang historis sosio-ekonomis mereka. Juga para nabi adalah jurubicara kaum miskin dan bahwa mazmur-mazmur adalah nyanyian-nyanyian gembira dari rakyat miskin. ${ }^{16}$ Dengan demikianlah kita melihat bagaimana para theolog dari bangsa India melihat pembebasan dari penderitaan dan kemiskinan yang mereka alami.

\section{Teologi di Jepang}

\section{Jepang dalam Sejarah}

Dari sudut ekonomi, Jepang merupakan suatu bangsa yang membentuk suatu kekuatan ekonomi yang dahsyat di dunia ini. Penghasilan bruto dan perkapitanya tinggi. Dari sudut historis, Jepang berambisi menahlukkan dan menguasai Asia. Bahkan akibat kekuatan Jepang di Asia, membuat banyak bangsa Asia menderita. Kenangan penderitaan itu masih amat kuat ditemukan di antara bangsa-bangsa Asia sekarang ini. Dalam situasi sekarang pun, Jepang secara ekonomi bertumbuh semakin kuat. Bahkan Jepang masih dipandang sebagai penyebab banyak penderitaan di Asia. Karenanya, Jepang tidak dapat digolongkan miskin secara materi, seperti India dan Indonesia, yang terus berjuang melepaskan diri dari kemiskinannya. ${ }^{17}$

Tapi itu tidak berarti, bahwa Jepang telah bebas dari segala bentuk penderitaan atau bangsa yang tidak mengalami penderitaan lagi. Di Jepang ditemui ada orang-orang yang paling menderita karena kebijaksanaan menelantarkan dan mendiskriminasikan para petani miskin, para pekerja yang dibayar murah, para pekerja harian, orang-orang yang tersingkirkan, orang-orang cacat, para pendu- duk Korea di Jepang, orang-orang Okinawa

\footnotetext{
${ }^{14}$ Choan-Seng Song, Allah yang Turut Menderita (Jakarta: BPK Gunung Mulia, 1990), 130

${ }^{15}$ Ibid

${ }^{16}$ Elwood, Teologi Kristen Asia, 356

${ }^{17}$ Yewangoe, Theologia Crusis di Asia, 170
} 
dan bangsa Ainer. Di tengah-tengah modrenisasi Jepang, semua orang ini telah dikorbankan demi pengaturan kekuasaan; hak-hak pemilikan tanah dan pekerjaan mereka disangkal, serta secara sosial diperlakukan sebagai budak dan orang-orang tak berguna. ${ }^{18}$

Selain bentuk penderitaan di atas, ada lagi bentuk penderitaan yang lain yaitu gejala keterasingan satu dari yang lain. Di mana faktor-faktor sosial dan ekonomi amat dalam mempengaruhi masyarakat Jepang, membuat keberadaan mereka amat kaku dan biokrasi. Hal ini menyebabkan hilangnya secara bertahap rasa komunitas di mana-mana. Ini merupakan ancaman terhadap komu- nitas manusia. ${ }^{19}$ Jadi, walaupun dikatakan Jepang itu makmur, tapi suatu bentuk penderitaan dalam hati setiap Jepang ada. Ini mereka ungkapkan melalui literatur, khususnya dalam drama klasik.

Karena itu, dalam lubuk hati bangsa Jepang masih ada kemampuan untuk merasakan apa artinya dan apakah penderitaan itu sebenarnya. Perasaan demikian berakar dalam Buddhisme dan Shinto/ Kong $\mathrm{Hu} \mathrm{Cu}$. Rasa penderitaan ini berakar dalam hati setiap orang Jepang, setiap kali Jepang ditimpa bencana dan kemalangan. Dan ini terjadi tahun 1929 dan 1930, mengakibatkan banyak orang hidup dalam keadaan miskin dan pengangguran di perkotaan membuat mereka semakin sadar akan makna penderitaan. Juga pada perang Dunia II dicirikan dengan "masa kematian dan kepedihan," Jepang secara konkrit mengalami penderitaan. ${ }^{20}$

\section{Pengaruh Buddhisme terhadap Penderitaan}

Walaupun Jepang memiliki agama sendiri (Shinto), tetapi Buddhisme memainkan peranan penting dalam kehidupan bangsa Jepang. Bagi Jepang Buddhisme sebagai "tradisi," karena ia adalah sesuatu yang terkadung dalam kehidupan bangsa Jepang, apapun agamanya. Dengan demikian, doktrin dukkha memainkan peranan penting. Bagi Buddhisme, kehidupan manusia dikuasai oleh lingkaran kelahiran, kematian dan kembali kekelahiran. Tepatnya, "suatu proses lingkaran tanpa akhir." Dengan demikian, orang terikat pada kesinambungan proses "kembali menjadi" atau "kelahiran kembali." Sejauh manusia menemukan dirinya dalam lingkaran kembali ini, ia pun masih berada dalam situasi dukkha. ${ }^{2 l}$ Cara lain untuk tiba pada akhir dukkha yang dengannya nirvana dapat terealiser. Realisasi terhapusnya penderitaan dalam nirvana digambarkan dengan istilah-istilah: tidak tertanggu, tidak terciptakan, kekal, tidak terhapuskan, hilangnya penderitaan, kebebasan dari keinginan, tak terkaitkan, pantai di seberang, yang di depan, ketiadaan, tidak dapat dipahami, terhapusnya penindasan, yang mutlak, yang tidak terancam, yang tidak terkait, tak ada maut, kelepasan, kemerdekaan, pembebasan terakhir, tidak ada nafsu, ketenangan, kemurnian, penyembuhan. ${ }^{22}$

Nirvana cendrung dipandang sebagai sesuatu yang terletak di luar yang "negatif" dan "posi- tif." Nirvana tidak dapat digambarkan semata-mata suatu keberadaan, keadaan

\footnotetext{
${ }^{18}$ Ibid., 171

${ }^{19}$ Ibid., 172

${ }^{20}$ Ibid., 172-173

${ }^{21}$ R.S.Sugirtharajah, Wajah Yesus di Asia (Jakarta: BPK Gunjung Mulia, 2003), 49

${ }^{22}$ A.G.Honig, Jr., Ilmu Agama (Jakarta: BPK Gunjung Mulia 1966)
} 
dimana dukkha berakhir. Maka untuk dapat tiba pada akhir penderitaan ada disebut "delapan jalan utama" yang isi- nya: pengertian yang benar, pikiran yang benar, perkataan yang benar, perbuatan yang benar, cara hidup yang benar, daya upaya yang benar, perhatian yang benar, dan konsentrasi yang benar. ${ }^{23}$

\section{Gereja dan Masalah Keadilan}

Peranan orang-orang Kristen Jepang telah memberikan sumbangan besar bagi kemajuan sosial dan perkembangan kerohanian bangsa. Ini berarti, bahwa kekeristenan sebagai suatu unsur penting dalam kehidupan bangsa Jepang. Simpati yang diberikan kepada kekristenan dipandang dari motif -motif ekonomi dan politik. Situasi semacam ini membawa orang Kristen Jepang ke dalam posisi yang agak sulit dengan berbagai masalah sosial. Saat Jepang menjadi bangsa yang kuat, saat itu menjadi suatu kekuatan imperialis. Hal ini diperkuat pada keyakinan Shinto bahwa kaisar adalah penjelmaan hidup dari Amaterasimikami, dan mengadakan invansi-invansi terhadap tetangga-tetangganya. ${ }^{24}$

Orang-orang Kristen Jepang diminta sikap mereka terhadap invasi-invasi tersebut. Dengan demikian, orang-orang Kristen Jepang dipaksa ke dalam suatu situasi krisis. Karena itu, ketika Jepang menyerbu tetangga-tetangganya, sejumlah Gereja dan orang Kristen mendukung secara antusias. Dalam konferensi tiga agama (Shinto, Buddha, Kristen) telah diresmikan untuk bekerja sama guna mencapai tujuan pemerintah. Dewan Kristen Nasional sendiri membuat pernyataan akan mengabdikan diri demi memajukan tujuan kaisar dalam peperangan dan membangkitkan semangat berperang di seluruh negeri. Maka Gereja-gereja Jepang menghimbau orang-orang Kristen di Asia agar memahami dengan benar peranan Jepang di Asia yaitu menegakkan persaudaraan guna men- capai kemakmuran bersama Asia. ${ }^{25}$

\section{Penderitaan dan Perjanjian Lama}

Pengalaman Jepang masa perang dunia II banyak orang terkena penderitaan dan sengsara luar biasa, secara khusus, yang tersentuh peristiwa bom atom di Hirosima dan Nagasaki (Agustus 1945). Yang berjasa berusaha mengkontekstualisasikan pesan Injil kepada situasi hidup di Jepang masa itu ialah Kitamori. Dimana Kitamori secara serius memperhitungkan konsep Buddhis tentang dukkha dan pemahaman tentang tsurasa khas Jepang untuk memecahkan masalah penderitaan. Maka tesis utama Kitamori adalah "penderitaan ialah hakekat Allah." Dengan tesis ini, Kitamori menentang pandangan tradisional yang memahami Allah tidak dapat menderita. ${ }^{26}$

Karena itu "penderitaan" merupakan intisari Injil di Jepang. Nas Perjanjian Lama yang dikutip dalam membicarakan "penderitaan" di Jepang seperti Yeremia 31:20 dengan mengatakan"'Saya diperbolehkan mengalami ke dalaman hati Allah." Menurut Kitamori, Yeremia mencirikan "Paulus dalam Perjanjian Lama," maka "Allah pada salib" bagi Paulus adalah "Allah yang menderita" bagi Yeremia. Maksudnya, Allah yang menderita

\footnotetext{
${ }^{23}$ Ibid, 161

${ }^{24}$ Yewangoe, Theologia Crusis di Asia, 200

${ }^{25}$ Ibid.

${ }^{26}$ Ibid., 208
} 
adalah Allah yang memecahkan penderitaan manusia kita melalui penderitaan-Nya sendiri. Karena itu, bila dikatakan "penderitaan adalah hakekat Allah" itu bermaksud penderitaan bukan sekedar penderitaan karena simpati atau empati dengan sengsara manusia, tetapi penderitaan dalam keberadaan Allah sendiri sebagai Allah; penderitaan yang menjadi bagian, yang ikut membentuk karakter ilahi Allah. ${ }^{27}$

Selain itu Ayub 7:11-21 juga dikutip sebagai dasar membicarakan "penderitaan" manusia. Dalam penderitaan, manusia dapat menemukan dirinya menemukan dunia di sekitarnya, terutama menemukan Allah. Untuk menemukan Allah, orang-orang bisa mulai dengan kehidupan mereka yang dibebani oleh penderitaan yang dialaminya. Dengan cara demikianlah dahulu Israel kuno menemukan Allah. Dan dengan cara demikian jugalah orang Jepang menemukan Allah yang turut menderita. Maka kehidupan di dalam dan dari penderitaan inilah dimulai pencarian akan Allah. ${ }^{28}$

Nas lain yang dikutip membicarakan penderitaan di Jepang adalah Yes 63:15. Dalam ayat ini kata Ibrani yang diterjemahkan dengan "hatiku terharu" dan "kasih sayang." Maka dalam nas ini kata (דָָָה ) "hama" menyaratkan "penderitaan" dan "kasih" dapat dipertukarkan dan atau diper- gunakan berbarengan. Maka kabar baik Allah mengahapuskan penderitaan dan penyembuhan luka- luka kita, terkait dengan "penderitaan" Allah. Nas ini juga dihubungkan dengan Yehezkiel 5:13 di mana murka Allah itu mutlak dan tegas. Maka, orang harus dihukum karena dosa mereka kepada Allah. Jadi, Allah menghukum orang berdosa dan mengasihinya. ${ }^{29}$

Dalam kata "hati-Ku terharu" terdengar suara dari Allah yang bergumul. Allah harus meng- hukum, harus bergumul dengan Allah yang mengasihi. Kenyataannya, Allah yang bergumul dengan diri-Nya, bukanlah dua Allah yang berbeda, menyebabkan Ia menderita. Ia sambil mengutip kata- kata M. Luther: "Di sanalah Allah bergumul dengan Allah." Titik akhir pergumulan Allah dengan Allah terjadi di Golgata. Maka peristiwa salib, di mana Anak Allah mati, bukan suatu peristiwa yang terjadi di luar Allah. Pada salib Allah mematikan diri-Nya sendiri, dengan demikian menye- lesaikan masalah kematian kita sendiri. $^{30}$

Dalam hubungan ini, satu lagi perlu kita dengar dari Perjanjian Lama yaitu konsep tentang "hamba Tuhan" yang menderita dalam kitab Yesaya. Konsep ini memberikan penjelasan yang sangat terang terhadap simbolisasi penderitaan. Penderitaan manusia harus dipandang sebagai repre- sentasi, refleksi, ungkapan dan aktualisasi penderitaan Allah. Jadi, penderitaan "hamba Tuhan" hanyalah lambang dari penderitaan yang menebus, dan bukan penderitaan yang menebus itu sendiri. Dengan kata lain, penderitaan "hamba Tuhan" adalah "lambang" dari penderitaan di dalam Yesus Kristus. Jelasnya, hamba Tuhan yang menderita sebagai lambang dari penderitaan Allah dalam Yesus Kristus. Dengan cara demikianlah Allah membebaskan manusia dari penderitaannya. ${ }^{31}$

\footnotetext{
${ }^{27}$ Ibid.

${ }^{28}$ Song, Allah yang Turut Menderita, 238

${ }^{29}$ Ibid.

${ }^{30}$ Yewangoe, Theologia Crusis di Asia, 209

${ }^{31}$ Ibid., 215
} 


\section{Teologi di Korea}

\section{Istilah dan Pengertian}

Istilah Minjung merupakan ungkapan bagi orang yang disingkirkan dan dirampok subjektivitasnya oleh yang berkuasa. Kata Minjung ini berasal dari dua ungkapan huruf Cina yaitu min dan jung. Kata min diterjemahkan "rakyat" dan kata jung diterjemahkan "massa." Maka gabungan kedua kata Minjung berarti "massa rakyat" atau secara singkat disebut saja "rakyat." 32 Sehingga ada yang bertanya "siapakah Minjung itu?" Pertanyaan ini didasarkan atas realitas yang dinamis dan hidup. Maka secara konkrit Minjung adalah "kaum tak punya." Mereka adalah petani, nelayan, buruh, penganggur, tentara, polisi, juru bayar gaji, penilik warung, produsen kecil. Mereka menderita penindasan politik, penghisapan ekonomi, pencemohan sosial dan keterasingan budaya. ${ }^{33}$

Pengertian yang lain tentang Minjung adalah mereka yang tertindas secara politik, dihisap secara ekonomi, terasing secara sosiologis dan secara budaya dan intelektual dipertahankan untuk tetap tidak berpendidikan. Dalam situasi di mana kekuasaan politik memainkan peranan yang domi-nan, yang tertindas secara politik adalah kaum Minjung. Jadi Kaum Minjung ada di mana-mana. Karena itu Minjung tidak dapat disamakan dengan proletar, karena kaum proletar hanya mengacu pada mereka yang secara idiologis dan ekonomi tergolong pada suatu kelas tertentu dalam masyarakat, sementara Minjung mempunyai konotasi historis yang lebih pribadi dan luas. ${ }^{34}$

\section{Korea dalam Sejarah}

Ada yang perlu diketahui bagaimana penderitaan kaum Korea (Selatan) dewasa ini. Bila diban-dingkan dengan negara Asia lainnya, Korea secara ekonomi sudah maju, tapi masih berbeda dalam situasi penderitaan. Penderitaan dimaksudkan di sini yaitu karena Korea telah terbagi dua (Utara dan Selatan), secara mendalam merusak kehidupan bangsa Korea, menyebabkan kehancuran dan penderitaan yang tak terperikan; dan bangsa Korea masih hidup dalam konflik dengan pemerintahan mereka sendiri yang menindas. Jadi dapat dikatakan, rakyat Korea hanya dapat dipahami dalam hubungan kekuasaan seluruh sejarah rakyat adalah sejarah penderitaan. ${ }^{35}$

Rakyat dirampok subyektivitasnya, baik dalam ungkapan, tindakan dan perasaan mereka. Kesadaran mereka ditentukan oleh kelas yang berkuasa. Mereka tidak diperbolehkan mengambil keputusan untuk nasib dan arah hidupnya sendiri. Karenanya, dari perspektif rakyat, sejarah pada hakekatnya adalah sejarah berkuasa. Ia tidak pernah menjadi sejarah rakyat. Kelas yang berkuasa adalah subjek sejarah. Situasi seperti ini sangat menyakitkan, sehingga penderitaan ini berakar dalam pengalaman sejarah rakyat. Karenanya, penderitaan rakyat mempunyai akar dalam sejarah kebudayaan dan agama

\footnotetext{
${ }^{32}$ Jung Young Lee (ed)., An Emerging the Theology in World Perspective Commentary on Korean Minjung Theology (Seoul: Benedict Press, 1984), 3

${ }^{33}$ Amirtham dan Pobee, Teologi oleh Rakyat, 36-37. Lihat juga: Yewangoe, Theologia Crusis di Asia, 120

${ }^{34}$ Ibid., 120-121

${ }^{35}$ Amartham dan Pobee, Teologi oleh Rakyat, 39
} 
rakyat. Artinya, penderitaan rakyat tidak hanya suatu masalah politis, tetapi juga sesuatu mengenai kebudayaan rakyat. ${ }^{36}$

\section{Minjung Memahami Penderitaan}

Para teolog Minjung Korea memandang Minjung sebagai mereka yang telah memprotes dan memberontak terhadap situasi mereka yang menindas. Mereka tidak semata-mata menerima nasib dan jalan hidup mereka sebagaimana adanya. Tetapi, Minjung berupaya melepaskan diri dari situasi yang menyengsarakan, meskipun hasilnya membawa pada penindasan lebih besar. Akibatnya, Minjung merasa tidak berdaya dan menekan kerinduan. Satu-satunya cara mengungkapkan penderitaan dan kerindua terjadi lewat suatu "bahasa khusus" yaitu han (natiniah), cerita dan tari topeng di antara kaum Minjung. ${ }^{37}$

(1). Mengenai han. Apa arti han itu? Para theolog Korea belum sepaham mengenai arti han ini. Namun, dari keberagaman itu ada suatu kesamaan, dan kesamaan itulah yang dibicaran di sini. Han adalah rasa penderitaan yang mendalam akibat tekanan ketidakadilan terhadap rakyat. Rasa penderitaan akibat tekanan yang tak berdaya itu adalah inti biografi dari seorang Korea secara pribadi. Ada mengatakan, agar arti han lebih jelas bagi bangsa Korea, lebih tepat menyisipkan dua buah cerita yaitu kemtian Nona Kim dan kasus Bruder Oh Wan-Choon. ${ }^{38}$

Kedua contoh memberikan gambaran tentang han, yaitu dalam kematian Nona Kim, kita tidak hanya melihat berbagai struktur politik dan ekonomi Korea. Tetapi juga perwujudan han dari delapan juta kaum buruh. Ini adalah han dari kaum tertindas. Hal yang sama dapat dikatakan bagi kasus Bruder Oh Wan-Choon. Di mana, penderitaan para buruh dan petani Korea terpusat pada penderitaan Nona Kim dan Bruder Oh Wan-Choon. Jadi, kontradiksi dalam sistem ekonomi dan politik Korea adalah bagian yang tidak terpisahkan dari kedua cerita ini. Maka han adalah perasaan umum dari rakyat Korea yang tidak berdaya. Inilah akumulasi pengalaman penindasan yang terte- kan dan dipadatkan , yang diwarisi dan diteruskan, yang mendidih dalam hati rakyat. ${ }^{39}$

(2). Mengenai cerita. Han dari Minjung adalah "bahasa" rakyat, juga terungkap lewat "ceri-ta." Melalui "cerita" ini, Minjung melancarkan kritik mereka terhadap kelas yang berkuasa. Cerita- cerita ini sering bersifat satiris.Cerita-cerita klassik Korea terkenal seperti Dongsangking Chan, juga melaluai novel seperti Chang-ma (musin hujan) oleh Yoon Hyung-kill, cerita tentang suara oleh Kim Chi-ha, Shin Goong (Busur Allah) oleh ChunSeung-se. Ada juga yang melalui puisi yang ditulis dengan tema han. Melalui cerita inilah Minjung memahami diri mereka terhadap kelas berkuasa, dalam usaha mereka untuk mendapatkan kesadaran sosial yang lebih besar, kritik diri yang membangun dan kelepasan dari situasi yang sengsara. ${ }^{40}$

\footnotetext{
${ }^{36}$ Ibid

${ }^{37}$ Yewangoe, Theologia Crusis di Asia, 130

${ }^{38}$ Bd. C.S.Song, Sebutkanlah Nama-nama Kami (Jakarta: BPK Gunung Mulia, 1993), 20

${ }^{39}$ Ibid. Lihat juga: Lee, An Emerging the Theology in World Perspective Commentary on Korean Minjung Theology, 8-10, 68-70 Suatu pembahasan yang luas tentang han

${ }^{40}$ Untuk cerita yang lebih luas mengenai hal ini diceritakan oleh David Kwang-sun Suh, dalam Amartham dan Pobee, Teologi oleh Rakyat, 33-38
} 
Maka melalui "cerita" ini juga Minjung berusaha menyelesaikan han (kemarahan)nya. Karena penyebab han tidak dicari dalam nasib, atau dalam kehendak Allah, tetapi dalam kerakusan manusia dan kontradiksi-kontradiksi sosial. Para penguasa telah menyebabkan rakyat jatuh miskin dan menderita. Karena itu, kelepasan dari penderitaan harus diwujudkan dengan menyelesaikan han itu, dan han hanya dapat dipecahkan melalui usahanya sendiri. ${ }^{41}$

(3) Tari topeng. Ungkapan bahasa Minjung yang lain adalah "tari topeng." Maksud pertama- nya adalah sebagai penghiburan. Tarian ini menolong orang melupakan beban hari itu dan kekuatir- an hari esok. Melalui tari topeng komunitas dibangun. Tetapi bukan ini mksud satu-satunya. Choan- Seng Song melihat pentingnya tari topeng dalam konteks sosial, politik dan keagamaannya. Melalui tari topeng digambarkan penderitaan kaum miskin, yang tertindas oleh si kaya. Secara religius, tari topeng menunjukkan betapa dekatnya Allah kepada manusia, baik dalam dan ketidak berkenan-Nya. Jadi, tari topeng bisa menjadi seruan, permohonan, doa dari suatu komunitas yang menghadapi masalah. Kekuatan dari tari topeng ini muncul dari pengalaman transendensi kritis. ${ }^{42}$

Tarian topeng ini berakar pada festival-festival tua pedesaan, yang dilakukan satu atau dua kali setahun sebagai upacara keagamaan, dengan maksud meminta berkat hasil yang lebih baik. Ciri tari topeng ini satiris. Pertunjukan terdiri dari tarian, musik instrumental berirama, nyanyian dan dialog antara pemain dan musikus, pemain dan penonton. Sifat satiris dari tari topeng ini terletak terletak pada kenyataan dipakai untuk mengkeritik penindas Minjung, ketimbang menenangkan dewa seperti yang dilakukan. ${ }^{43}$

\section{Minjung dan Perjanjian Lama}

Para teolog Minjung melihat penderitaan Minjung secara khusus dalam penderitaan umat Israel yang tertindas oleh penguasa sebagaimana dikisahkan dalam kitab Keluaran. Karenanya, peristiwa Keluaran sebagaimana dikisahkan dalam Perjanjian Lama memperoleh makna penting dalam theologia Minjung. Peristiwa Keluaran ini dipandang sebagai penegasan kedudukan Minjung (yakni bangsa Israel yang tertindas) sebagai subjek berdasarkan keadilan Allah sebagai Tuhan sejarah yaitu TUHAN (YHWH). ${ }^{44}$

Para theolog Minjung melihat, inti sejarah Perjanjian Lama dan awal mula rakyat (Minjung = Israel). Biografi sosial Minjung adalah suatu sejarah suatu bangsa yang menderita sebagai bagian dari seluruh pengalaman sejarah, ditangkap ke dalam kedaulatan Allah dengan jalan mengakui Allah sebagai protogonis dalam biografi sosial ini. Dari titik inilah kebanyakan theolog Minjung melihat kesamaan antara Minjung dari peristiwa Keluaran (bangsa Israel) dan Minjung Korea yaitu penderitaan dan penindasan yang dialami oleh Minjung. Kesamaan terletak dalam hubungan Minjung dengan kelas yang berkuasa. Di mana, Minjung dalam sejarah Keluaran adalah kaum tertindas, haknya

\footnotetext{
${ }^{41}$ Ibid, 39

${ }^{42}$ Yewangoe, Theologia Crusis di Asia, 135

${ }^{43}$ Ibid.

${ }^{44}$ Ibid., 153. Band. Sugirtharajah, Wajah Yesus di Asia, 261-265. Di sini Minjung disamakan dengan Yesus yang menderita; maka dengan cara demikianlah orang Korea mengindentifikasikan dirinya dengan penderitaan Yesus.
} 
diperkosa. Karena itu, Minjung harus dipahami dalam kontras dengan struktur-struktur kekuasaan. ${ }^{45}$

Teologi Minjung, melihat peristiwa Keluaran sebagai salah satu paradigma bagi theologia Minjung. Ia melihat peristiwa Keluaran sebagai salah satu dari dua peristiwa inti bagi keselamatan umat Allah, dengan penyaliban dan kebangkitan Yesus sebagai peristiwa kedua. Karenanya, seluruh kesaksian Alkitab dapat dijelaskan dan dipahami dalam arti dua peristiwa sejarah inti. Di mana, peristiwa Keluaran adalah suatu peristiwa politik yang terjadi dalam bidang sosial-ekonomi. Pemberontakan melawan penindasan sosial-ekonomi dipahami sebagai suatu tindakan pemberontakan melawan sistim Mesir yang berkuasa dan menindas. Ini adalah peristiwa politik yang membentuk inti cerita. ${ }^{46}$

Tetapi Keluaran bukanlah satu-satunya sebagai dasar bagi penderitaan dan perjuangan Minjung. Selain peristiwa Keluaran, yang dipandang sebagai objek pembebasan, tetapi juga sebagai objek berkat dalam ciptaan, yaitu Kejadian 1:28-30. Walaupun ada keberbedaan, di mana Israel tertindas di Mesir kerena kealfaannya terhadap berkat Kej 1:28-30. Tapi ketika Israel di pembuangan, kitab Kejadian menegaskan bahwa Allah berkuasa, dengan demikian menawarkan berkat dan kekuasaan. Karena itu, kata "manusia sebagai gambar Allah" dipahami sebagai dasar tentang harkat manusia. Manusia (rakyat, Minjung) mempunyai hubungan yang khusus dengan Allah. Karena itu, manusia (rakyat) mempunyai suatu kedudukan khusus dalam ciptaan. Penciptaan manusia sebagai gambar Allah menjelaskan nilai manusia, harkat manusia. Maka pemulangan adalah pemulihan martabat manusia yang datang dari luar manusia. ${ }^{47}$

Selain Kejadian 1:28-30 dapat dilihat lagi dalam kitab Mika, di sana kata "umat-Ku" tidak lain dalam arti Minjung. Kata "umat-Ku" berdiri bertentangan dengan musuh-musuh Allah, yakni para penguasa, yang berkuasa; dalam kitab Mika digambarkan sebagai "bangsa ini." Karena itu, kata "umat-Ku" dalam kitab Mika tidak lain daripada mereka yang tak berpunya, yang tertindas, yang terasing. Gambaran-gambaran yang serupa juga kita temukan dalam kitab Amos; di mana mereka telah dirampok harta benda dan hak-hak azasi manusianya, digambarkan dengan "kaum miskin, kaum tertindas dan yang tak berdaya." ${ }^{48}$ Demikianlah theolog Korea memahami Minjung dari sudut Perjanjian Lama.

\section{KESIMPULAN}

Pembahasan theologia di Asia yang dilihat dalam perspektif Perjanjian Lama pada dasarnya tidak berbeda, walaupun di sana-sini dalam setiap bangsa (India, Jepang dan Korea) mempunyai variasi akan pengalaman mereka dalam penderitaan dan kemiskinan mereka alami. Bagaimana pun latar belakang penderitaan dan kemiskinan mereka, tapi semuanya itu dapat dirumuskan dengan ungkapan yang sama yaitu "penderitaan dan kemiskinan." Hal perlu dipahami lagi, setiap bangsa memahami penderitaan mereka dari sudut budaya dan agama asli mereka masing-masing. Juga dari sudut budaya dan agama

\footnotetext{
${ }^{45}$ Yewangoe, Theologia Crusis di Asia, 153

${ }^{46}$ Ibid.

${ }^{47}$ Ibid., 154

${ }^{48}$ Ibid., 155-156
} 
asli mereka masing-masing juga mengupayakan pembebasan dari pende- ritaan dan kemiskinan yang mereka alami.

Jelasnya, setiap bangsa, baik itu India, Jepang dan Korea membangun theologia mereka berdasarkan konteks yang mereka alami masing-masing bangsa. Kalau pun mereka memakai nas-nas Alkitab yang sama, misalnya peristiwa Keluaran, tetapi peristiwa Keluaran itu mereka kon- tekstualisasikan berdasarkan pengalaman mereka akan penderitaan dan kemiskinan tersebut. Dari pengalaman dan penderitaan yang mereka alami itulah para theolog melihat kepada Alkitab, dan mereka berupaya untuk mengindentifikasikan hidup mereka sama seperti penderitaan dan kemiskin- an yang dialami oleh umat Allah dalam Perjanajian Lama. Dengan demikianlah para theolog Asia mendengar suara Perjanjian Lama itu juga adalah suara kepada bangsa mereka.

\section{REFERENSI}

Amirtham, Samuel \& Pobee, John S. Theologia oleh Rakyat, Jakarta: BPK Gunung Mulia, 1993

Elwood, J. Teologi Kristen Asia, Jakarta: BPK Gunung Mulia, 1992

Honig Jr, A.G., Ilmu Agama, Jakarta: BPK-G.M, 1966

Lee, Jung Young. An Emerging the Theology in World Perspektive Commentary Korean Minjung Theology, Soul: Benedict Press, 1984

Mawene, Marthinus Th. Teologi Kemerdekaan, Jakarta: BPK Gunung Mulia, 2004

Sugirtharajah, R.S. Wajah Yesus di Asia, Jakarta: BPK Gunung Mulia, 2003

Song, Choan-seng. Allah Yang Turut Menderita, Jakarta: BPK Gunung Mulia, 1990

---------. Sebutkanlah Nama-nama Kami, Jakarta: BPK Gunung Mulia, 1993

Yewangoe, A.A. Theologia Crusis di Asia, Jakarta: BPK Gunung Mulia, 1989 